Intracellular Localization of Titanium Dioxide-Biomolecule Nanocomposites

T. Paunesku, N. Stojicevic, ${ }^{*}$ S. Vogt, ${ }^{\ddagger}$ J. Maser, ${ }^{\ddagger}$ B. Lai, ${ }^{\ddagger}$ T. Rajh, ${ }^{\dagger}$ M. Thurnauer, ${ }^{\dagger}$ and G. Woloschak ${ }^{* \S}$

*Department of Radiology, Northwestern University, 303 E. Chicago Ave, Chicago, IL 60611

${ }^{\ddagger}$ SRI-CAT, Advanced Photon Source, ${ }^{\dagger}$ Chemistry Division, Argonne National Laboratory, 9700 South Cass Avenue Argonne, IL 60439-4833

${ }^{\S}$ To whom correspondence and reprint requests should be addressed.

E-mail: g-woloschak@,northwestern.edu; phone (312) 503 4322; fax (312) 5032544 
T. Paunesku, N. Stojicevic, S. Vogt, J. Maser, B. Lai, T. Rajh, M. Thurnauer, and G. Woloschak

This space should be left blank, except for the names of the authors. (The publisher will re-type the main title, author names and addresses. Please give this information on a separate page.)

\begin{abstract}
Emerging areas of nanotechnology hold the promise of overcoming the limitations of existing technology for intracellular manipulation. These new developments include the creation of nanocomposites that can be introduced into the cells, targeted to specific subcellular sites, and subsequently used as platforms for initiation of intracellular processes dependent on or aided by locally high concentrations of specific molecules delivered as components of the nanocomposites. Nanocomposites that combine functional properties of biomolecules with the functional properties of inorganic components could provide new tools for biology, medicine, chemistry and material sciences. Here we describe how we introduced $\mathrm{TiO}_{2}$-DNA nanocomposites into cells, and localized titanium in the cells by mapping the Ti K $\alpha$ X-ray fluorescence induced at the 2-ID-E microprobe of the SRI-CAT at the Advanced Photon Source at Argonne National Laboratory.
\end{abstract}

\title{
1. RESULTS
}

Biological-chemical nanocomposites composed of titanium dioxide and DNA described by T. Rajh et al. (in revision) can be introduced into mammalian HL60 cells in culture either alone or in combination with additional "free" oligonucleotides. Detection of these nanocomposites in cells was accomplished by detection of titanium using a hard X-ray fluorescence microprobe. We described some possible uses of the hard X-ray fluorescence microprobe for elemental mapping [1]; here we specifically show detection of titanium that enables us to determine the cellular (and subcellular) localization of $\mathrm{TiO}_{2}$-DNA nanocomposites.

Grids with cells were mounted on standardized kinematic specimen holders and placed in the specimen chamber of the 2-ID-E X-ray fluorescence microprobe at the Advanced Photon Source at Argonne National Laboratory. The specimen chamber was filled with helium to optimize the detection of $\mathrm{X}$-ray fluorescence of lighter elements, and to minimize the X-ray fluorescence background from argon gas in the air. A tunable, monochromatic X-ray beam from an undulator X-ray source was focused in a $0.5 \mu \mathrm{m} \times 0.3 \mu \mathrm{m}$ spot using a Fresnel zone plate. Incident photon energy of $9.8 \mathrm{keV}$ was chosen, which allows excitation of $\mathrm{K}_{\alpha} \mathrm{X}$-ray fluorescence in elements with atomic numbers $\mathrm{Z}$ between $15(\mathrm{P})$ and 30 $(\mathrm{Zn})$. An energy dispersive detector collected X-ray fluorescence radiation from the specimen; energy filtering of the measured spectra allowed identification of the elemental constituents in the illuminated specimen volume. To obtain a map of the elemental distribution in the cell, the specimen was scanned in $\mathrm{x}$ and $\mathrm{y}$ while recording the X-ray fluorescence spectra. We simultaneously mapped the fluorescent signatures of $\mathrm{P}, \mathrm{S}, \mathrm{Cl}, \mathrm{K}, \mathrm{Ca}, \mathrm{Ti}, \mathrm{Mn}, \mathrm{Fe}, \mathrm{Cu}$, and $\mathrm{Zn}$.

In Fig. 1, X-ray fluorescence maps are shown of the elements $\mathrm{P}, \mathrm{S}, \mathrm{Cl}, \mathrm{K}, \mathrm{Ca}, \mathrm{Ti}, \mathrm{Mn}, \mathrm{Fe}, \mathrm{Cu}$ and $\mathrm{Zn}$ in an $82 \times 82 \mu \mathrm{m}$ area containing twenty-eight HL60 cells transfected with $\mathrm{TiO}_{2}$-DNA oligonucleotide nanocomposites. The map of the Ti distribution in this specimen shows that seven cells contain titanium as a consequence of transfection. Of these cells five had Ti signal peaks higher than $5 \mu \mathrm{g} / \mathrm{cm}^{2}$ (blue color on this figure), and two lower. One such cell with a peak Ti signal higher than $5 \mu \mathrm{g} / \mathrm{cm}^{2}$ is indicated by a pink arrow; it contains a total of $2.9 \times 10^{7} \mathrm{TiO}_{2}$ nanoparticles (each nanoparticle contains about $1400 \mathrm{Ti}$ atoms). 


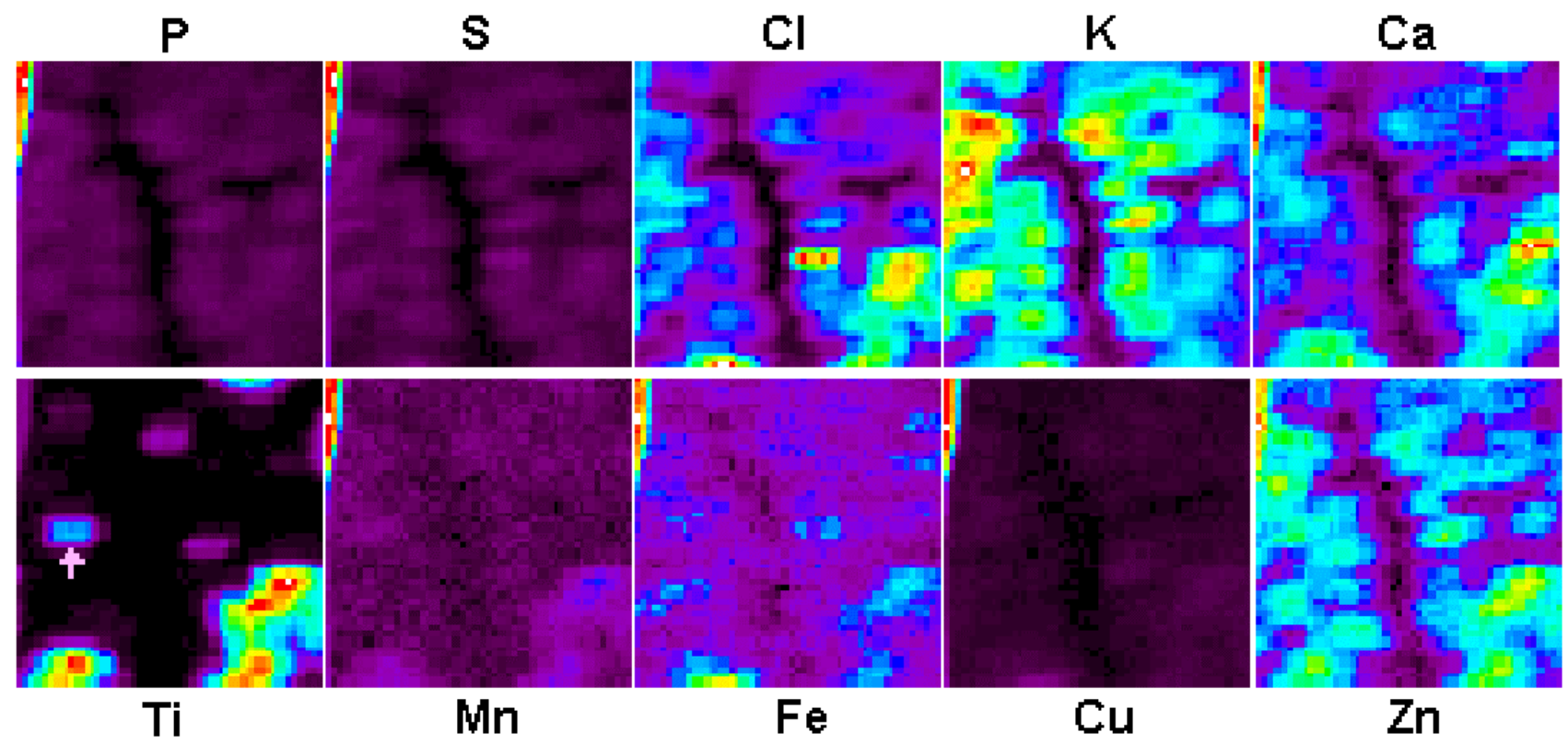

Figure 1. Mapping $\mathrm{TiO}_{2}$-DNA nanocomposites in mammalian cells using $\mathrm{Ti}_{\alpha} \mathrm{X}$-ray fluorescence, with $2 \mu \mathrm{m} \times 2 \mu \mathrm{m}$ step scan of a $82 \mu \mathrm{m}$ x $82 \mu \mathrm{m}$ area containing 26 cells transfected by $\mathrm{TiO}_{2}-\mathrm{DNA}$ nanocomposites, and "free" DNA oligonucleotide. (In the image color scheme the highest signal intensity is white, lowest black.)
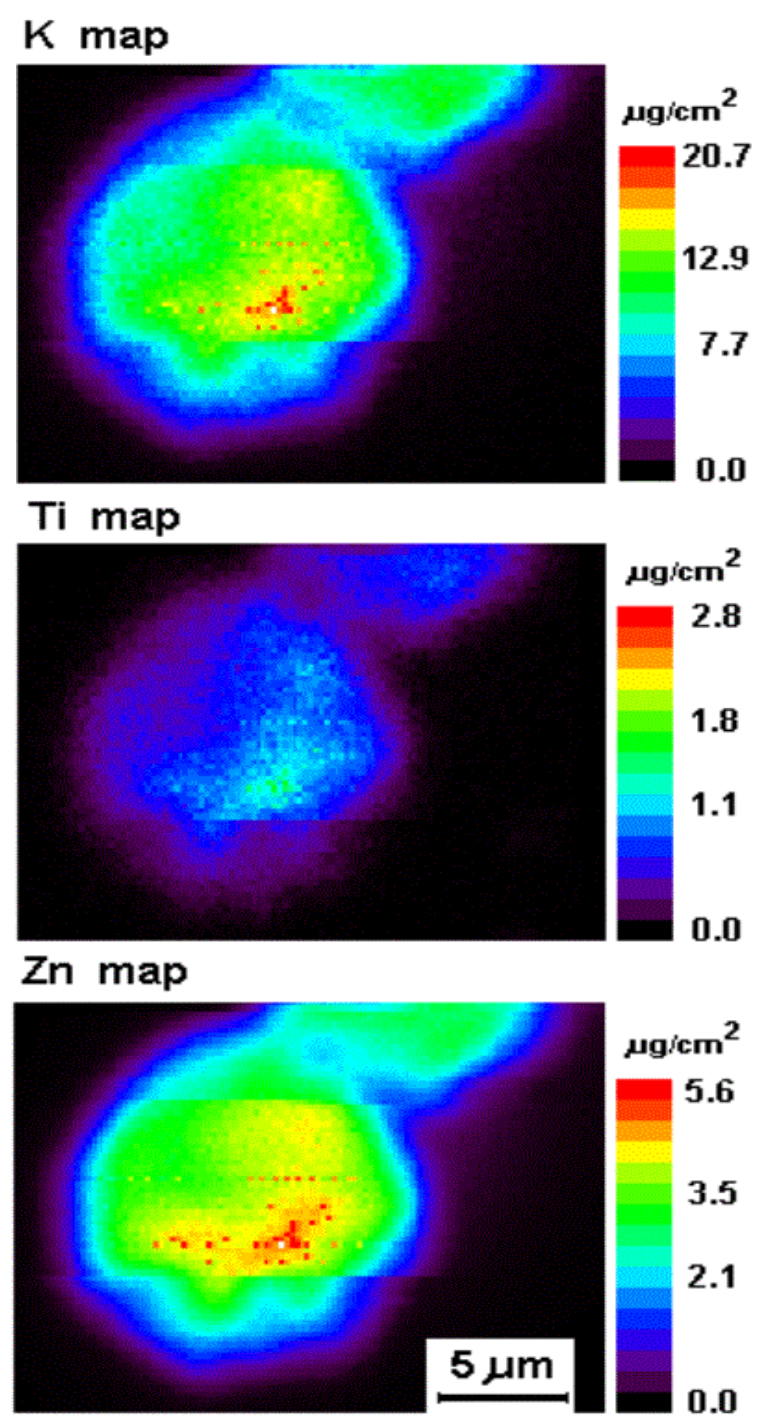

Figure 2. Mapping $\mathrm{TiO}_{2}$-DNA nanocomposites in a single mammalian cell nucleus using Ti $\mathrm{K}_{\alpha} \mathrm{X}$-ray fluorescence, with 0.2 $\mu \mathrm{m} \times 0.2 \mu \mathrm{m}$ step scan of a nucleus isolated from cells transfected by $\mathrm{TiO}_{2}$-DNA nanocomposites. Nuclei were isolated according to the procedure of Pichon and Christophe [2]. Signal intensity bars show concentration of metals in $\mu \mathrm{g} / \mathrm{cm}^{2}$. 
Fig. 2 shows a high resolution scan of a $12 \times 12 \mu \mathrm{m}^{2}$ area of a single nucleus containing $3.6 \times 10^{6}$ nanoparticles. This nucleus was isolated from whole cells transfected with both $\mathrm{TiO}_{2}$-DNA nanocomposite, and a "free" DNA oligonucleotide. This scan demonstrates that the $\mathrm{TiO}_{2}$-DNA nanocomposites, once introduced into mammalian cells, reach the nucleus.

A series of scans of the same type as above was obtained for 514 cells from 24 different samples of cells transfected with seven different Ti nanocomposites, either alone or in combination with "free" oligonucleotides. Table 1 presents the percentages of cells showing the presence of Ti signal. Chi square analysis (with 2 degrees of freedom) of the contingency table of these data showed, at a confidence level greater than 0.995, that there is an association of transfection success and addition of "free" oligonucleotides to transfection mixtures. Sequence of the "free" oligonucleotides, either identical to the sequence of the DNA attached to the nanocomposite or heterologus (different when compared to the sequence of oligonucleotide bound to Ti nanoparticle) did not affect this association.

Table 1. Percentages of cells (of 514 cells transfected with seven different $\mathrm{TiO}_{2}$ nanoparticle-oligonucleotide nanocomposites in 24 experiments) displaying Ti signal.

\begin{tabular}{|c|c|c|c|}
\hline \multirow{2}{*}{ Peak Ti Signal Intensity } & \multicolumn{3}{|c|}{ Added Oligonucleotide } \\
\cline { 2 - 4 } & None & Heterologous DNA & Identical DNA \\
\hline$>5 \mu \mathrm{g} / \mathrm{cm}^{2}$ & 14.1 & 13.3 & 27.3 \\
\hline$<5 \mu \mathrm{g} / \mathrm{cm}^{2}$ & 14.1 & 35.8 & 22.2 \\
\hline None & 71.7 & 50.8 & 50.5 \\
\hline
\end{tabular}

\section{CONCLUSIONS}

- Nanocomposites, a new tool for intracellular manipulations, can be engineered to provide biomolecules with novel functional properties (from the inorganic partner) and to provide inorganic molecules with unique specificity (from the bound DNA).

- Standard transfection methods can be employed to introduce $\mathrm{TiO}_{2}$-DNA nanocomposites into cells. Once intracellular, these nanoparticles are able to translocate into the cell nucleus.

- Addition of "free" oligonucleotides to cell transfection mixtures changes the numbers of transfected cells per total number of cells in the sample, and the peak Ti signal intensity in the transfected cells.

- X-ray fluorescence excited in a hard X-ray microprobe can be used to quantify the success rate of transfection and reveal the intracellular distribution of the nanocomposites.

\section{Acknowledgments}

This work was supported by NIH grants CA81375, CA73042, and NS 21442. Use of the Advanced Photon Source was supported by the U.S. Department of Energy, Basic Energy Sciences, Office of Science, under Contract No. W-31-109-Eng-38.

\section{References}

[1] Lai B., Maser J., Paunesku T., and Woloschak G.E., Report on Workshop of Biological Applications of X-ray Microbeams, International Journal of Radiation Biology 78(8) (2002) 749-752.

[2] Pichon B., and Christophe D., An in vitro transcription system for the study of thyroid-specific transcription, Anal. Biochem. 261 (1998) 233. 